\title{
Protein-protein interaction between ezrin and p65 in human breast cancer cells
}

\author{
R. Tang, F.X. Li, W.F. Shao, Q.S. Wen, X.R. Yu and J.B. Xiong \\ Department of Cell Biology, School of Basic Medical Sciences, \\ Southern Medical University, Baiyun District, Guangzhou, \\ Guangdong Province, China \\ Corresponding author: J.B. Xiong \\ E-mail: jbxiong@smu.edu.cn \\ Genet. Mol. Res. 15 (2): gmr.15028334 \\ Received December 23, 2015 \\ Accepted February 11, 2016 \\ Published June 30, 2016 \\ DOI http://dx.doi.org/10.4238/gmr.15028334
}

\begin{abstract}
Our study aimed to investigate the co-localization and protein-protein interactions between ezrin and p65 in human breast cancer cells. Liquid chromatography-mass spectrometry (LCMS) was used to uncover novel protein interactions with ezrin in MDA-MB-231 cells. Endogenous co-immunoprecipitation was used to validate protein-protein interactions between ezrin and p65 in MDA-MB-231. Exogenous interactions between ezrin and p65 were validated in MDAMB-231 cells via Flag-ezrin and HA-p65 co-transfection and followed by co-immunoprecipitation. Immunofluorescence staining was used to visualize ezrin and p65 co-localization in MDA-MB-231. LCMS results showed that there were 1000 proteins interacting with ezrin in MDA-MB-231 cells. Ezrin and p65 interactions were confirmed with both endogenous and exogenous methods. We were also able to visualize ezrin and p65 co-localization in MDA-MB-231. In summary, we found protein-protein interactions between Ezrin and p65 in human breast cancer cells.
\end{abstract}

Key words: Ezrin; p65; Breast cancer; Interaction 


\section{INTRODUCTION}

Breast cancer is the most frequently diagnosed cancer, and accounts for $25 \%$ of all cancer cases and $15 \%$ of all cancer-related deaths in women. It is the leading cause of cancerrelated death worldwide; with an estimated occurrence of 1.7 million cases and 521,900 deaths in 2012 (Torre et al., 2015). It is known that most breast cancer patients die from metastasis (Marino et al., 2013) and resistance to chemotherapy (Li et al., 2015). Therefore, understanding the underlying mechanism of cancer metastasis and chemoresistance is important for the development of molecular target-based therapies in breast cancer patients.

Recently, advances in molecular profiling were reported to offer more accurate predictions on cancer metastasis and treatments as well as enabling the selection of therapeutic targets (Cyr and Margenthaler, 2014).

Ezrin is a member of the ERM (ezrin-radxin-moesin) family, which was originally discovered to be a component of the intestinal brush border microvilli (Bretscher, 1983). It was then identified as the major component of microvilli in the placenta (Bretscher, 1989). Ezrin was found to be associated with various types of cancer, such as colon cancer (Gavert et al., 2010), pancreatic cancer (Meng et al., 2010), and gastric cancer (Li et al., 2011). In addition, studies have also reported on correlations between ezrin overexpression and breast cancer development/ metastasis (Elliott et al., 2005; Mak et al., 2012; Ghaffari et al., 2014). Short hairpin RNA-mediated knockdown of ezrin in MDA-MB-231 cells led to an increase in cell adhesion and a decrease in cell migration (Szeto et al., 2013), suggesting that ezrin may regulate focal adhesion dynamics.

NF- $\kappa B$ was first identified in 1986 as the transcription factor for the $\kappa$-immunoglobulin light chain in B lymphocytes (Sen and Baltimore, 1986), and was found to be closely associated with breast cancer. Biswas et al. (2001) found that NF- $\mathrm{KB}$ activity was significantly higher in patients with estrogen receptor (ER)-negative breast cancer as compared with ER-positive breast cancer patients. This was especially true in infiltrating ductal carcinoma with poor tissue differentiation and during lymphatic metastasis (Singh et al., 2007), suggesting that constitutive activation of NF-KB may be an important step in the pathogenesis of ER-negative breast cancer. The p65/p50 heterodimer is the main form of NF- $\mathrm{BB}$ (Lernbecher et al., 1993), and the p65 subunit is closely associated with the biological activity of breast cancer cells (Pande et al., 2013).

Studies have examined the effect of p65 and ezrin knockdowns on tumor metastasis in various types of cancers (Wu et al., 2014; Qu et al., 2015). However, few studies have examined the interactions between ezrin and p65, and their effects on tumor invasion and migration. Therefore, we investigated the interaction between ezrin and p65 in breast cancer cells in order to determine whether they contribute to tumor invasion and migration, and to provide potential new drug targets for breast cancer treatments.

\section{MATERIAL AND METHODS}

\section{Cell cultures}

MDA-MB-231 were obtained from the cell resource center of Shanghai Academy of Sciences, Chinese Academy of Sciences (Shanghai, China). MDA-MB-231 cells were cultured in Leibovitz's L-15 medium (Thermo Fisher Scientific Inc., Shanghai, China) containing $10 \%$ fetal bovine serum (FBS; Gibco, Thermo) at $37^{\circ} \mathrm{C}$ with saturated humidity and without $\mathrm{CO}_{2}$. Culture media were replaced every 2 to 3 days, and cells were subcultured in trypsin- 
ethylenediaminetetraacetic acid (EDTA, 0.25\%, Solarbio Technology Co., Ltd., Shanghai, China) when confluence reached $85-90 \%$.

\section{Coomassie brilliant blue (CBB) and silver staining}

Immunoprecipitation (IP) samples prepared from whole cell lysate of MDA-MB-231 cells incubated with ezrin antibody (Cell Signal Technology, Inc. and Sigma, USA) were analyzed by sodium dodecyl sulfate-polyacrylamide gel electrophoresis (SDS-PAGE) using a $10 \%$ separating gel, and were stained with CBB G250 (Brunelle and Green, 2014) and silver nitrate (Chevallet et al., 2006), separately, according to a previous protocol. Silver nitrate protein bands were recovered and stored in $\mathrm{ddH}_{2} \mathrm{O}$.

\section{Liquid chromatography-mass spectrometry (LCMS)}

IP samples and recovered protein bands from silver staining were sent to GigaScience (Shenzhen, China) for LCMS.

\section{Plasmid construction}

The cDNA sequence of Ezrin was obtained from Zhoushan Tongsheng Biotechnology Co., Ltd. (Zhoushan, China). The ezrin gene was amplified by polymerase chain reaction (PCR), and subcloned into pcDNA3.1 vectors (Invitrogen ${ }^{\mathrm{TM}}$, Thermo) to construct plasmid pcDNA3.1 Flag-ezrin. The primers for Flag-ezrin were designed with the Primer premier 6.0 software (Premier Biosoft, USA), and synthesized by Invitrogen ${ }^{\mathrm{TM}}$ (Table 1). The amplifying system and reaction conditions for construction of pcDNA3.1 Flag-ezrin are listed in Tables 2 and 3. The endonuclease and ligation system for construction of pcDNA3.1 Flag-ezrin are described in Tables 4 and 5. PCR products were analyzed by 3\% agarose gel electrophoresis. Plasmid DNA was recovered with the DNA purification kit (Thermo) and stored at $-20^{\circ} \mathrm{C}$. HA-p65 plasmids, which were already transformed into DH5 $\alpha$ competent cells, were obtained from the First Affiliated Hospital of Sun Yat-sen University (Guangzhou, China).

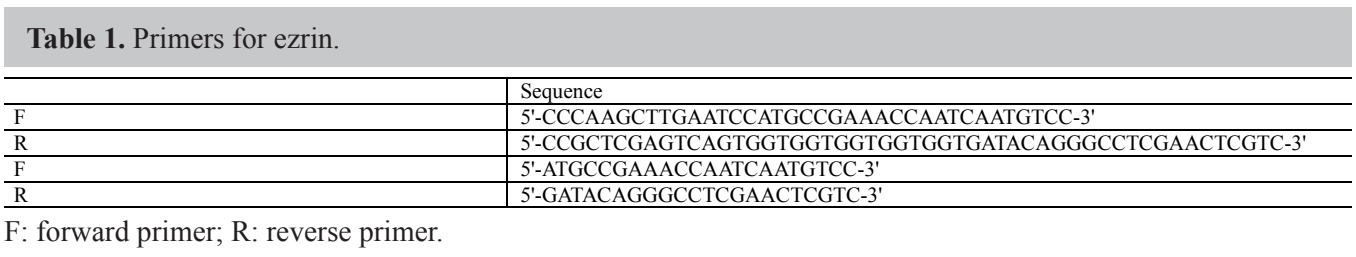

\begin{tabular}{|c|c|}
\hline & Volume $(\mu \mathrm{L})$ \\
\hline DNA template & 4 \\
\hline \multirow[t]{2}{*}{ Primers } & F: 1 \\
\hline & $\mathrm{R}: 1$ \\
\hline dNTPs & 4 \\
\hline Kod plus Neo & 0.5 \\
\hline PCR buffer $\left(\mathrm{Mg}^{2+}\right)$ & 5 \\
\hline $\mathrm{ddH}_{2} \mathrm{O}$ & 34.5 \\
\hline Total & 50 \\
\hline
\end{tabular}

F: forward primer; R: reverse primer. 
Table 3. PCR conditions for ezrin.

\begin{tabular}{l|c|c|c}
\hline Step & Temperature $\left({ }^{\circ} \mathrm{C}\right)$ & Time & Cycle number \\
\hline Pre-degeneration & 94 & $2 \mathrm{~min}$ & \multirow{2}{*}{30 cycles } \\
\hline Degeneration & 98 & $10 \mathrm{~s}$ & \\
\hline Annealing & 60 & $30 \mathrm{~s}$ & 1 cycle \\
\hline Extension & 68 & $2 \mathrm{~min}$ & $5 \mathrm{~min}$ \\
\hline Extension terminal & 68 & $\rightarrow \infty$ & \\
\hline Storage & 4 & $\rightarrow$ \\
\hline
\end{tabular}

Table 4. Enzymatic system for Flag-Ezrin.

\begin{tabular}{l|c}
\hline & \multicolumn{1}{|c}{ Volume $(\mu \mathrm{L})$} \\
\hline PCR product & 12 \\
\hline & 3 \\
\hline Hin $\mathrm{dIII} / \mathrm{Xba \textrm {I }}$ & $1 / 1$ \\
\hline $\mathrm{ddH}_{2} \mathrm{O}$ & 13 \\
\hline Total & 30 \\
\hline
\end{tabular}

Table 5. Ligation system for Flag-Ezrin.

\begin{tabular}{l|c}
\hline & Volume $(\mu \mathrm{L})$ \\
\hline $10 \mathrm{X}$ Ligase buffer & 1 \\
\hline HindIII $/ \mathrm{ba} \mathrm{I}$ & 0.2 \\
\hline Fragment & 7.8 \\
\hline T4DNA ligase & 1 \\
\hline Total & 10 \\
\hline
\end{tabular}

\section{Competent DH5 $\alpha$ cells}

DH5 $\alpha$ cells were obtained from Professor X.C. Bai (Department of Cell Biology, Southern Medical University), and were stored at $-80^{\circ} \mathrm{C}$ with $50 \%$ glycerol and $50 \%$ LuriaBertani (LB) medium (Gibco). Inoculated DH5 $\alpha$ cells were cultured overnight at $37^{\circ} \mathrm{C}$ and $220 \mathrm{rpm}$ in $1 \% \mathrm{LB}$ with ampicillin $(50 \mathrm{mg} / \mathrm{mL}, 1: 100)$. Control DH5 $\alpha$ cells were cultured at $37^{\circ} \mathrm{C}$ and $220 \mathrm{rpm}$ in LB without ampicillin for $1 \mathrm{~h}$. DH5 $\alpha$ cells were then transferred into a pre-cooled tube and placed on ice for $5 \mathrm{~min}$. Sterilized $\mathrm{CaCl}_{2}(0.1 \mathrm{M})$ was added to the cells, which were placed on ice for $30 \mathrm{~min}$, followed by centrifugation at $4000 \mathrm{~g}$ and incubation at $4^{\circ} \mathrm{C}$ for $10 \mathrm{~min}$. Cells were then resuspended in sterilized $\mathrm{CaCl}_{2}(0.1 \mathrm{M})$ and $50 \%$ glycerol, and stored at $-80^{\circ} \mathrm{C}$.

\section{Heat-shock transformation of DH5a with pcDNA3.1 Flag-ezrin}

pcDNA3.1 Flag-ezrin ( $1 \mu \mathrm{L}$, at $>100 \mathrm{mg} / \mathrm{mL})$ was added to $100 \mu \mathrm{L}$ DH5 $\alpha$ cells on ice for $30 \mathrm{~min}$. Cells were heated at $42^{\circ} \mathrm{C}$ in water for $90 \mathrm{~s}$, followed by immediate incubation on ice for $2 \mathrm{~min}$. Transformed cells were cultured in LB without ampicillin at $220 \mathrm{rpm}$ and $37^{\circ} \mathrm{C}$ for $1 \mathrm{~h}$. Cells were then centrifuged at $4000 \mathrm{~g}$ for $5 \mathrm{~min}$ and resuspended in $50 \mathrm{~mL} \mathrm{LB}$. Cells were inoculated on LB plates with ampicillin and cultured at $37^{\circ} \mathrm{C}$ for $12-20 \mathrm{~h}$. A single clone was randomly selected and cultured in LB with ampicillin at $220 \mathrm{rpm}$ and $37^{\circ} \mathrm{C}$ for $8-16 \mathrm{~h}$. Cells were centrifuged at $3000 \mathrm{~g}$ for $3 \mathrm{~min}$, resuspended in LB with ampicillin, then stored at $-80^{\circ} \mathrm{C}$. 


\section{Plasmid extraction}

The pcDNA3.1 Flag-ezrin and HA-p65 plasmids were extracted with the plasmid mini kit (Tiangen Biotech Co., Ltd., Beijing, China) according to manufacturer protocol. The concentrations of the plasmids were detected using the Nanodrop 2000. Plasmids were stored at $-20^{\circ} \mathrm{C}$ and were sequenced by Invitrogen ${ }^{\mathrm{TM}}$ (Thermo).

\section{Endogenous co-IP}

MDA-MB-231 cells were cultured on 3-cm plates (Corning-Costar, New York, USA) until they reached $90 \%$ confluence. Media were then discarded, and the cells were washed with PBS (Boster Bioengineering Co., Ltd., Wuhan, China) on ice. Pre-cooling IP lysis buffer (0.5 mL; $50 \mathrm{mM}$ Tris- $\mathrm{HCl}, 150 \mathrm{mM} \mathrm{NaCl}, 1 \mathrm{mM}$ EDTA-2Na, 1\% Triton-X 100, $0.5 \mathrm{mM}$ sodium pyrophosphate, $1 \mathrm{mM} \beta$-glycerophosphate and $1 \mathrm{mM} \mathrm{Na} \mathrm{VO}_{4}$; Boster) containing a protease inhibitor cocktail (PIC, 1:100, Sigma Aldrich Co., LLC, Shanghai, China) was added. After samples were incubated on ice for $10 \mathrm{~min}$, cells were scraped and gently rotated at $4^{\circ} \mathrm{C}$ for $20 \mathrm{~min}$. Cells were then centrifuged at $12,000 \mathrm{~g}$ and $4^{\circ} \mathrm{C}$ for $10 \mathrm{~min}$. Supernatant was collected, and input $(50 \mu \mathrm{L})$ was taken from the supernatant. Anti-ezrin (1:50, Cell Signal Technology, Inc.) and anti-p65 (1:50) antibodies were added. IgG (ZSGB Biotechnology Co., Ltd., Beijing, China), used as the control, was added to another cell lysate of MDA-MB-231 with the same concentration as the anti-ezrin antibody. Samples were rotated at $4^{\circ} \mathrm{C}$ overnight.

Protein A + G agarose (Beyotime Biotechnology Co., Ltd., Shanghai, China) was prepared and washed for 3 times with IP lysis buffer containing PIC. Samples were mixed with protein $\mathrm{A}+\mathrm{G}$ agarose, separately, and rotated at $4^{\circ} \mathrm{C}$ for $2 \mathrm{~h}$. They were then washed for three times with IP lysis buffer, and proteins were eluted with $35 \mu \mathrm{L} 2 \mathrm{X}$ loading buffer $(100 \mathrm{mM}$ Tris-HCl, pH 6.8, 4\% SDS, $0.5 \%$ bromophenol blue, $20 \%$ glycerol, $2 \% \beta$-mercaptoethanol, Solarbio). Eluded proteins were stored at $-20^{\circ} \mathrm{C}$.

\section{Exogenous co-IP and transfection}

MDA-MB-231 cells were cultured on 3-cm plates until they reached $70 \%$ confluence. Cells were co-transfected with pcDNA3.1 Flag-ezrin and HA-p65 (1:1) by Lipofectin ${ }^{\circledR}$ transfection reagent 3000 (Thermo) according to manufacturer specifications. Cells were immunoprecipitated according to the aforementioned protocol after $48 \mathrm{~h}$ of transfection. AntiFlag (1:100, Beijing Ray Antibody Biotech, Co., Ltd., Beijing, China) and anti-HA (1:1000, Proteintech Group Inc., Wuhan, China) antibodies were used for immunoprecipitation. The samples were store at $-20^{\circ} \mathrm{C}$.

\section{Western blot (WB)}

The protein concentrations were determined using the method developed by Lowry et al. (1951) with BSA serving as standards. Samples containing 30-250 $\mu$ g proteins were ran on SDS-PAGE with a 5\% stacking gel and a $10 \%$ separating gel. Proteins were transferred to polyvinylidene fluoride membranes (Millipore Corporate, Billerica, MA, USA). Following the transfer, the membranes were blocked for $2 \mathrm{~h}$ with PBS containing $0.05 \%$ Tween-20 and $5 \%$ non-fat milk at room temperature and then incubated with primary antibodies (anti-Ezrin 
1:4000, anti-p65 1:6000, anti-Flag 1:8000, anti-HA 1:6000) at $4^{\circ} \mathrm{C}$ overnight. After washing with PBS, membranes were incubated with the appropriate secondary antibodies (1:3000, Jackson ImmunoResearch Laboratories Inc., USA). Protein bands were developed with electrochemiluminescence (Beyotime).

\section{Immunofluorescence (IF) staining}

Co-transfected and untransfected MDA-MB-231 cells were cultured on glass bottom plates (Nest Biotechnology Co., Ltd., Wuxi, China) at 25\% confluence. Cells were fixed in $4 \%$ paraformaldehyde (Solarbio) for $30 \mathrm{~min}$ at room temperature and quenched for $5 \mathrm{~min}$ with 30 $\mathrm{mM}$ glycine in PBS. They were then permeabilized with $0.5 \%$ Triton-X (Solarbio) for $5 \mathrm{~min}$ at room temperature. Unspecific binding was blocked with 5\% non-fat milk and 2\% BSA for 1 $\mathrm{h}$ at room temperature. Cells were incubated with primary antibodies (mouse anti-Ezrin 1:100, rabbit anti-p65 1:100, mouse anti-Flag 1:100, rabbit anti-HA $1: 100)$ at $4^{\circ} \mathrm{C}$ overnight. This was followed by 1 -h incubation with secondary antibodies (Fluor ${ }^{\mathbb{B}} 594$ goat anti-mouse and Fluor $^{\circledR} 488$ goat anti-rabbit) (1:500, ZSGB). Nuclei were stained with DAPI (4',6-diamidine-2phenylindole, Thermo), and immunofluorescence was observed with a confocal laser scanning microscope (Olympus Corporation, Beijing, China).

\section{RESULTS}

\section{Enrichment of ezrin-specific binding proteins shown by CBB and silver staining}

Following IP, the input and IP samples were analyzed by SDS-PAGE and stained with $\mathrm{CBB}$ and silver nitrate. IgG was used as control. As shown in Figure 1, bands can be seen on the gel for both IP and input samples. Difference in pattern of protein bands between IP and input samples, which indicated enrichment of specific binding proteins of ezrin, can be seen. The ezrin protein band appeared next to the $8-\mathrm{kD}$ band of the ladder.

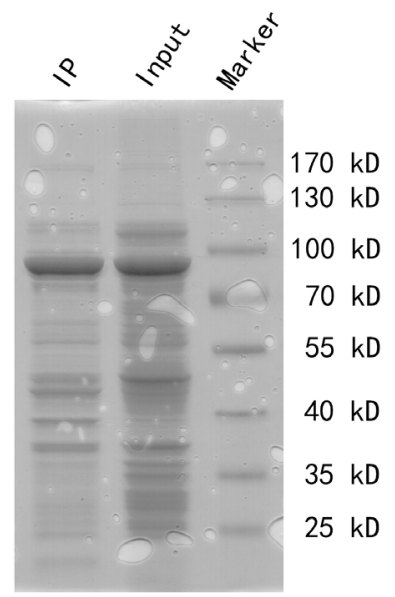

Figure 1. Coomassie brilliant blue staining of MDA-MB-231 after immunoprecipitation (IP). The MDA-MB-231 samples were analyzed by SDS-PAGE and then stained by CBB following IP. The protein accumulating at $80 \mathrm{kD}$ corresponds to ezrin. 
In the silver staining, bands were also found on the gel for input, IgG mouse control, and IP samples (Figure 2). Again, difference in pattern of protein bands between IP and IgG mouse control samples, which indicated enrichment of specific binding proteins os ezrin, can be seen. As expected, ezrin had an $80-\mathrm{kD}$ band.

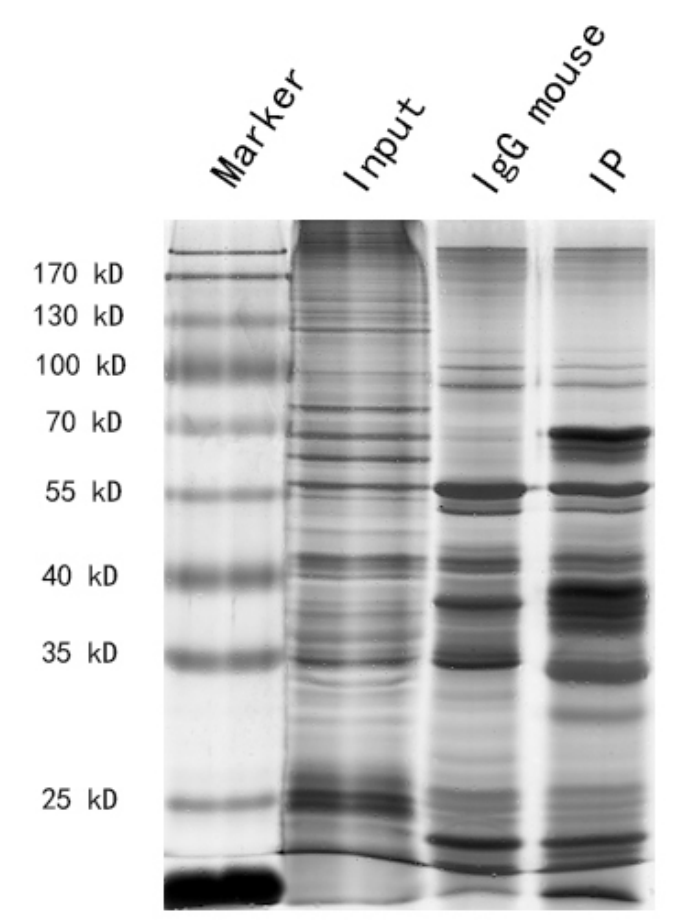

Figure 2. Silver staining of MDA-MB-231 after immunoprecipitation (IP). The MDA-MB-231 samples were analyzed by SDS-PAGE and then stained by silver nitrate. The protein accumulating at $80 \mathrm{kD}$ corresponds to ezrin. IgG mouse was taken as control.

\section{p65 is an ezrin binding protein detected by LCMS}

LCMS was conducted on the IP sample, which was previously stained with CBB. Notably, we were able to identify p65 in the IP sample via LCMS. In addition, protein p65 was also found to be in the recovered protein bands from silver staining. The results of LCMS are not included in this article.

\section{Ezrin and p65 binding identified by endogenous co-IP and WB}

As shown in Figure 3, using an anti-ezrin antibody (Figure 3A), we were able to detect three protein bands in three samples: Ezrin Input, Ezrin IP, and p65 IP. Similarly, using an anti-p65 antibody (Figure 3B), protein bands were detected in the samples of Ezrin IP, p65 Input, and p65 IP. 


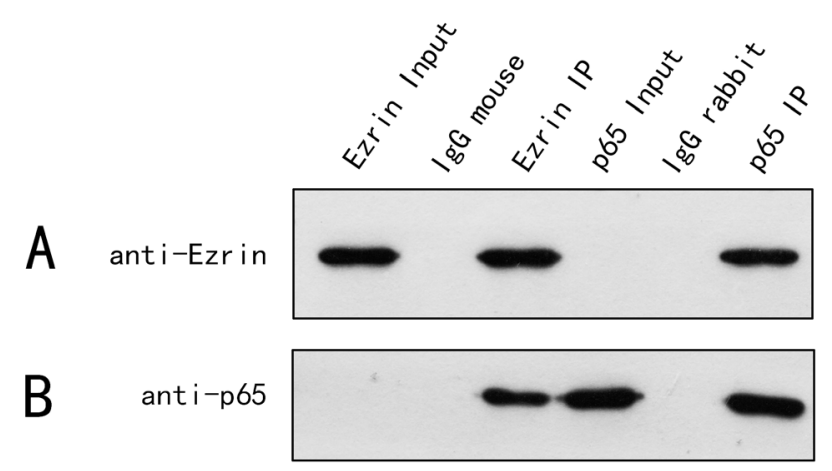

Figure 3. Western blot result of endogenous co-immunoprecipitation (IP) in MDA-MB-231. MDA-MB-231 samples were analyzed by western blot following IP. Anti-ezrin (A) and anti-p65 antibodies were used (B). "Ezrin Input" and "Ezrin IP" indicate ezrin staining, while "p65 IP" indicates p65 staining. IgG was taken as control.

\section{Ezrin and p65 binding identified by exogenous co-IP and WB}

As shown in Figure 4A, using the anti-Flag antibody, we were able to detect bands of IP Flag and IP HA samples. Similarly, using anti-HA antibody (Figure 4B), protein bands were detected in the samples of IP Flag and IP HA samples. Results confirmed that the anti-Flag antibody was able to immunoprecipitate HA-p65 fusion protein, while the anti-HA antibody was able to immunoprecipitate Flag-ezrin fusion protein.

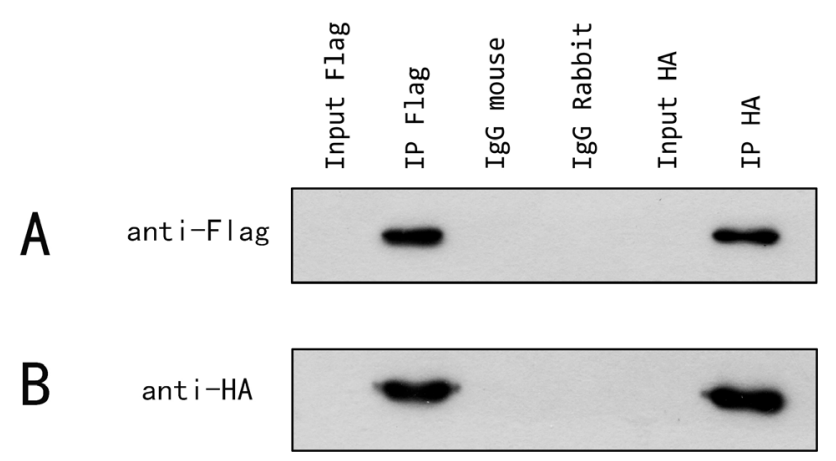

Figure 4. Western blot result of exogenous co-immunoprecipitation prepared from MDA-MB-231 with cotransfection of pcDNA3.1 Flag-Ezrin and HA-p65. Samples were detected by anti-Flag (A) and anti-HA antibodies (B). "Flag IP" and "Flag Input" indicate IP samples prepared by Flag antibody and its corresponding input samples. "HA IP" and "HA Input" indicate IP samples prepared by HA antibody and its corresponding input samples. "IgG mouse "and "IgG rabbit" are controls.

\section{Ezrin and p65 co-localization shown by IF staining}

As shown in Figure 5, the blue DAPI stained the nucleus (Figure 5A), the green fluorescence was indicative of the p65 protein (Figure 5B, anti-p65, Fluor ${ }^{\circledR} 488$ ), and the red fluorescence was indicative of the ezrin protein (Figure 5C, anti-Ezrin, Fluor ${ }^{\circledR}$ 594). The appearance of both green and the red (yellow) fluorescence supported p65 and ezrin colocalization (Figure 5D). 

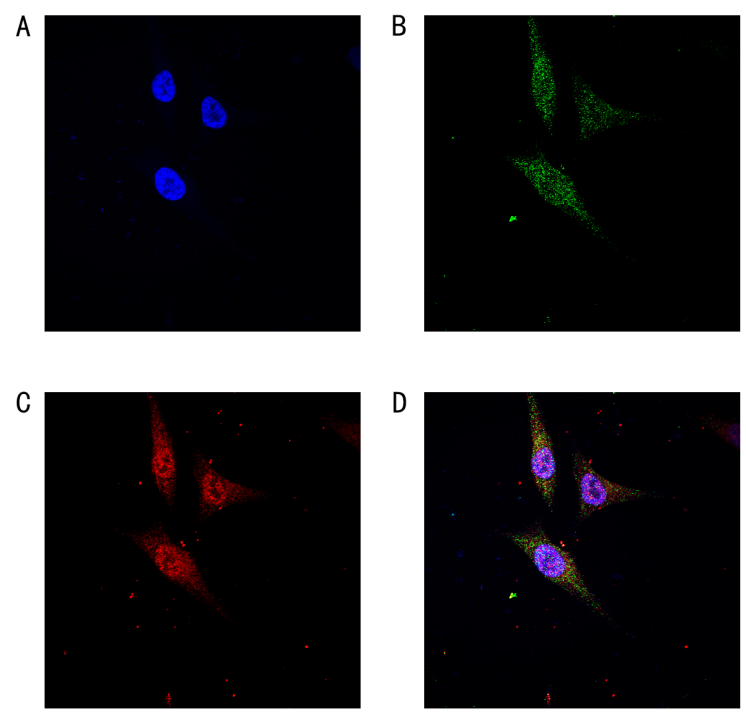

Figure 5. Immunofluorescence staining in MDA-MB-231 cells. MDA-MB-231 cell was stained for the nucleus (A, DAPI), p65 (B, anti-p65, Fluor $\left.{ }^{\circledR} 488\right)$, and ezrin (C, anti-Ezrin, Fluor ${ }^{\circledR}$ 594). Yellow immunofluorescence indicates co-localization between p65 and Ezrin (D).

As shown in Figure 6, MDA-MB-231 cells were also co-transfected with pcDNA3.1 Flagezrin and HA-p65. Again, nucleus was represented in blue (Figure 6A), p65 protein was shown in green (anti-HA, Fluor ${ }^{\circledR} 488$ ), ezrin protein was shown in red (anti-Flag, Fluor ${ }^{\circledR} 594$ ). The combination of green and red fluorescence indicated co-localization of HA-p65 and Flag-Ezrin (Figure 6D).

A
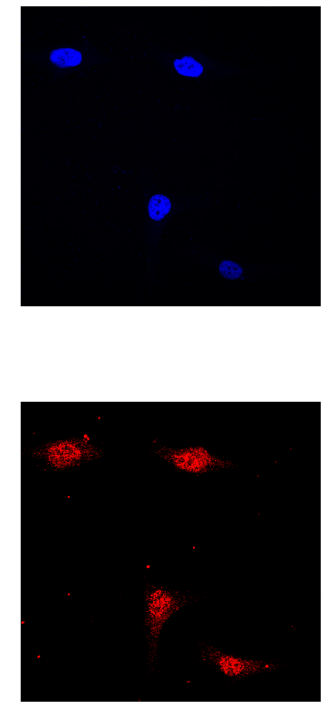

B

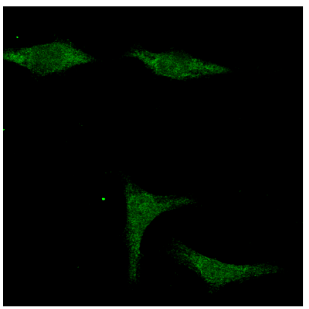

D

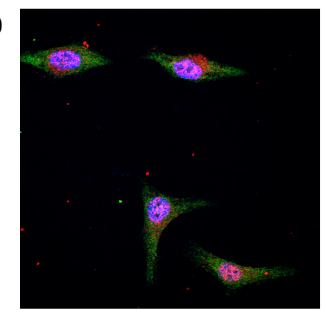

Figure 6. Immunofluorescence of MDA-MB-231 with Flag-Ezrin and HA-p65 co-transfection. Following cotransfection with Flag-Ezrin and HA-p65, MDA-MB-231 cells were stained for the nucleus (A, DAPI)), p65 protein (B, anti-HA, Fluor $\left.{ }^{\circledR} 488\right)$, and ezrin protein (C, anti-Flag, Fluor ${ }^{\circledR}$ 594). The combination of green and red indicates HA-p65 and Flag-Ezrin co-localization (D). 


\section{DISCUSSION}

Using co-IP and immunofluorescence, we were able to identify direct interactions between ezrin and p65 in the breast cancer lines MDA-MB-231. Similar results were found in MCF-7, and T47D as well as in the human renal epithelial cell line HEK-293T (data not shown). Wang et al. (2014) found that ezrin Tyr353 is phosphorylated via the Akt pathway, which induces activation of NF- $\mathrm{KB}$ in epidermal growth factor (EGF)-treated tongue squamous cell carcinomas (TSCCs). Using siRNA-mediated knockdown of ezrin, it was found that nuclear translocation of p65 following EGF treatment was inhibited in TSCC cells. Furthermore, EGF-induced epithelial-mesenchymal transition in TSCC cells was blocked, suggesting that ezrin plays critical roles in the metastasis and invasion of tumor cells. Ben-Shmuel et al. (2013) found that ezrin can be phosphorylated by L1 through Rho-associated protein kinase in colorectal cancer, and that ezrin might be associated with activation of NF-kB pathway, which results in tumor cell motility and an increase in the expression of insulin-like growth factor-binding protein 2. These results were consistent with research by Gavert et al. (2010) and Shvab et al. (2015).

However, no study has reported the co-localization and direct interaction between Ezrin and p65 in breast cancer cells. Ezrin was highly expressed on invasive tumors, and was strongly associated with cancer metastasis (Ghaffari et al., 2014). Therefore, we focused on determining the binding partners of ezrin. Following screening by LCMS, we selected p65 as our target protein. Not only does this protein interact with ezrin, but also has importance in the NF- $\mathrm{KB}$ signaling pathway, which is involved in tumor metastasis and invasion. IP, as the common method for identifying protein-protein interaction, was employed to examine the direct interactions between ezrin and p65. With endogenous co-IP methods, we confirmed endogenous interactions between Ezrin and p65 in MDA-MB-231 cells (Figure 3). Similar, but weaker interactions were also confirmed in MCF-7 and T47D cells (data not shown). We also carried out exogenous co-IP, in which MDA-MB-231 were first co-transfected with pcDNA3.1 Flag-Ezrin and HA-p65 prior to prepare whole cell lysate. The results confirmed exogenous interactions between ezrin and p65 (Figure 4). It is possible that the interaction between ezrin and $\mathrm{p} 65$ is involved in activation of NF- $\mathrm{KB}$ pathway leading to tumor metastasis.

As a subunit of the NF- $\mathrm{kB}$ transcription complex, $\mathrm{p} 65$ was found to be highly expressed in the lymph nodes of metastasizing primary prostate (Lessard et al., 2006) and non-small-cell lung cancer tumors (Zhang et al., 2012). The inhibitory effect of I- $\kappa B$ on cytoplasmic NF- $\kappa B$ is exerted primarily through interactions with the p65 subunit. Although p65 bound the DNA to activate transcription, its direct interactions with ezrin have not been studied. Due to its critical role in NF- $\mathrm{KB}$ signaling and its associations with ezrin, we investigated the interactions between ezrin and p65 in highly metastatic human cancer cell line MDA-MB-231. Previous studies have shown that by silencing p65, the invasive ability of MDA-MB-231 cells was reduced (Wang et al., 2011a). In addition, proliferation and apoptosis of MDA-MB-231 was inhibited and promoted, respectively (Wang et al., 2011b). Additionally, Wang et al. (2011c) also discovered that silencing p65 could arrest MDA-MB-231 at the G0/G1 phase, which may be mediated by the downregulation of cyclin D1 and upregulation of $\mathrm{p} 21$.

In our study, we co-stained ezrin and p65 in the cytoplasm of MDA-MB-231 cells. Previous research by Liu et al. (2015) showed that p65 interacts with small ubiquitin-related modifier 2/3 (SUMO2/3), which is a key regulator in the development of hepatocellular carcinoma (Qin et al., 2014). Moreover, p65 was regulated and stabilized in the cytoplasm 
by SUMO2/3 against the ubiquitin-proteasome system (UPS). The scaffolding protein Ezrinbinding phosphoprotein of $50 \mathrm{kDa}$ (EBP50) was also found to be associated with the UPS in a previous study (Song et al., 2015). Therefore, we speculate that the interactions between ezrin and p65 and their indirect or direct interaction with UPS and SUMO2/3 may affect the protein degradation system, which may contribute to metastatic and invasive abilities of MDA-MB-231 cells.

In conclusion, we discovered and identified interactions between ezrin and p65 in breast cancer cells. Further investigations need to be carried out to determine the effect of this interaction on the metastasis of breast cancer.

\section{Conflicts of interest}

The authors declare no conflict of interest.

\section{ACKNOWLEDGMENTS}

Research supported by the National Natural Science Foundation of China (\#81172058).

\section{REFERENCES}

Ben-Shmuel A, Shvab A, Gavert N, Brabletz T, et al. (2013). Global analysis of L1-transcriptomes identified IGFBP-2 as a target of ezrin and NF- $\mathrm{kB}$ signaling that promotes colon cancer progression. Oncogene 32: 3220-3230. http:// dx.doi.org/10.1038/onc. 2012.340

Biswas DK, Dai SC, Cruz A, Weiser B, et al. (2001). The nuclear factor kappa B (NF-kappa B): a potential therapeutic target for estrogen receptor negative breast cancers. Proc. Natl. Acad. Sci. USA 98: 10386-10391. http://dx.doi. org/10.1073/pnas. 151257998

Bretscher A (1983). Purification of an 80,000-dalton protein that is a component of the isolated microvillus cytoskeleton, and its localization in nonmuscle cells. J. Cell Biol. 97: 425-432. http://dx.doi.org/10.1083/jcb.97.2.425

Bretscher A (1989). Rapid phosphorylation and reorganization of ezrin and spectrin accompany morphological changes induce in A-431 cells by epidermal growth factor. J. Cell Biol. 108: 921-930. http://dx.doi.org/10.1083/jcb.108.3.921

Brunelle JL and Green R (2014). Coomassie blue staining. Methods Enzymol. 541: 161-167. http://dx.doi.org/10.1016/ B978-0-12-420119-4.00013-6

Chevallet M, Luche S and Rabilloud T (2006). Silver staining of proteins in polyacrylamide gels. Nat. Protoc. 1: 18521858. http://dx.doi.org/10.1038/nprot.2006.288

Cyr AE and Margenthaler JA (2014). Molecular profiling of breast cancer. Surg. Oncol. Clin. N. Am. 23: 451-462. http:// dx.doi.org/10.1016/j.soc.2014.03.004

Elliott BE, Meens JA, SenGupta SK, Louvard D, et al. (2005). The membrane cytoskeletal crosslinker ezrin is required for metastasis of breast carcinoma cells. Breast Cancer Res. 7: R365-R373. http://dx.doi.org/10.1186/bcr1006

Gavert N, Ben-Shmuel A, Lemmon V, Brabletz T, et al. (2010). Nuclear factor-kappaB signaling and ezrin are essential for L1-mediated metastasis of colon cancer cells. J. Cell Sci. 123: 2135-2143. http://dx.doi.org/10.1242/jcs.069542

Ghaffari A, Hoskin V, Szeto A, Hum M, et al. (2014). A novel role for ezrin in breast cancer angio/lymphangiogenesis. Breast Cancer Res. 16: 438. http://dx.doi.org/10.1186/s13058-014-0438-2

Lernbecher T, Müller U and Wirth T (1993). Distinct NF-kappa B/Rel transcription factors are responsible for tissuespecific and inducible gene activation. Nature 365: 767-770. http://dx.doi.org/10.1038/365767a0

Lessard L, Karakiewicz PI, Bellon-Gagnon P, Alam-Fahmy M, et al. (2006). Nuclear localization of nuclear factorkappaB p65 in primary prostate tumors is highly predictive of pelvic lymph node metastases. Clin. Cancer Res. 12: 5741-5745. http://dx.doi.org/10.1158/1078-0432.CCR-06-0330

Li L, Wang YY, Zhao ZS and Ma J (2011). Ezrin is associated with gastric cancer progression and prognosis. Pathol. Oncol. Res. 17: 909-915. http://dx.doi.org/10.1007/s12253-011-9402-y

Li S, Payne S, Wang F, Claus P, et al. (2015). Nuclear basic fibroblast growth factor regulates triple-negative breast cancer chemo-resistance. Breast Cancer Res. 17: 91. http://dx.doi.org/10.1186/s13058-015-0590-3 
Liu J, Sha M, Wang Q, Ma Y, et al. (2015). Small ubiquitin-related modifier 2/3 interacts with p65 and stabilizes it in the cytoplasm in HBV-associated hepatocellular carcinoma. BMC Cancer 15: 675. http://dx.doi.org/10.1186/s12885015-1665-3

Lowry OH, Rosebrough NJ, Farr AL and Randall RJ (1951). Protein measurement with the Folin phenol reagent. J. Biol. Chem. 193: 265-275.

Mak H, Naba A, Varma S, Schick C, et al. (2012). Ezrin phosphorylation on tyrosine 477 regulates invasion and metastasis of breast cancer cells. BMC Cancer 12: 82. http://dx.doi.org/10.1186/1471-2407-12-82

Marino N, Woditschka S, Reed LT, Nakayama J, et al. (2013). Breast cancer metastasis: issues for the personalization of its prevention and treatment. Am. J. Pathol. 183: 1084-1095. http://dx.doi.org/10.1016/j.ajpath.2013.06.012

Meng Y, Lu Z, Yu S, Zhang Q, et al. (2010). Ezrin promotes invasion and metastasis of pancreatic cancer cells. J. Transl. Med. 8: 61. http://dx.doi.org/10.1186/1479-5876-8-61

Pande D, Karki K, Negi R, Khanna S, et al. (2013). NF-אB p65 subunit DNA-binding activity: association with depleted antioxidant levels in breast carcinoma patients. Cell Biochem. Biophys. 67: 1275-1281. http://dx.doi.org/10.1007/ s12013-013-9645-1

Qin Y, Bao H, Pan Y, Yin M, et al. (2014). SUMOyla-881.

Qu Y, Zhang X and Wu R (2015). Knockdown of NF-kB p65 subunit expression suppresses growth of nude mouse lung tumor cell xenografts by activation of Bax apoptotic pathway. Neoplasma 62: 34-40. http://dx.doi.org/10.4149/ neo $2015 \quad 005$

Sen R and Baltimore D (1986). Inducibility of kappa immunoglobulin enhancer-binding protein Nf-kappa B by a posttranslational mechanism. Cell 47: 921-928. http://dx.doi.org/10.1016/0092-8674(86)90807-X

Shvab A, Haase G, Ben-Shmuel A, Gavert N, et al. (2015). Induction of the intestinal stem cell signature gene SMOC-2 is required for L1-mediated colon cancer progression. Oncogene [epub ahead of print].

Singh S, Shi Q, Bailey ST, Palczewski MJ, et al. (2007). Nuclear factor-kappaB activation: a molecular therapeutic target for estrogen receptor-negative and epidermal growth factor receptor family receptor-positive human breast cancer. Mol. Cancer Ther. 6: 1973-1982. http://dx.doi.org/10.1158/1535-7163.MCT-07-0063

Song GJ, Leslie KL, Barrick S, Mamonova T, et al. (2015). Phosphorylation of ezrin-radixin-moesin-binding phosphoprotein 50 (EBP50) by Akt promotes stability and mitogenic function of S-phase kinase-associated protein-2 (Skp2). J. Biol. Chem. 290: 2879-2887. http://dx.doi.org/10.1074/jbc.M114.609768

Szeto A, Hoskin V and Elliott BE (2013). Ezrin is required for adhesion and migration in invasive breast cancer. $B M C$ Proc. 7: 4. http://dx.doi.org/10.1186/1753-6561-7-S2-P4

Torre LA, Bray F, Siegel RL, Ferlay J, et al. (2015). Global cancer statistics, 2012. CA Cancer J. Clin. 65: 87-108. http:// dx.doi.org/10.3322/caac. 21262

Wang L, Shan BE and Sang MX (2011a). Effect of p65 gene on invasion of human triple-negative breast cancer cell line MDA-MB-231. Chin. J. Cancer Biother. 18: 502-507.

Wang L, Shan BE, Sang MX, Lian YS, et al. (2011b). [Effect of microRNA-mediated p65 gene silencing on the proliferation and apoptosis of human breast cancer MDA-MB-231 cells]. Nan Fang Yi Ke Da Xue Xue Bao 31: 1742-1747.

Wang L, Zhao LM and Zhang C (2011c). Effects of silencing p65 gene on cell cycle distribution of human breast cancer MDA-MB-231 cells. Cancer Res. Prevent. Treat. 38: 1236-1240.

Wang Y, Lin Z, Sun L, Fan S, et al. (2014). Akt/Ezrin Tyr353/NF-kB pathway regulates EGF-induced EMT and metastasis in tongue squamous cell carcinoma. Br. J. Cancer 110: 695-705. http://dx.doi.org/10.1038/bjc.2013.770

Wu B, Xie J, Du Z, Wu J, et al. (2014). PPI network analysis of mRNA expression profile of ezrin knockdown in esophageal squamous cell carcinoma. BioMed Res. Int. 2014: 651954. http://dx.doi.org/10.1155/2014/651954

Zhang XQ, Chen GP, Wu T, Yan JP, et al. (2012). Expression and clinical significance of ezrin in non-small-cell lung cancer. Clin. Lung Cancer 13: 196-204. http://dx.doi.org/10.1016/j.cllc.2011.04.002 